\title{
System of Strategic Priorities and Indicators of Ecologically Sustainable Subsoil Use
}

\author{
Yuriy Lebedev ${ }^{1,2}$, Nikolay Krupinin ${ }^{2}$, Vladimir Belov ${ }^{3}$ and Konstantin Kokarev ${ }^{2, a}$ \\ 1 Botanic Garden of the Ural Branch of the Russian Academy of Sciences \\ ${ }^{2}$ Ural State Mining University, Russia \\ 3 Yugra State University, Russia
}

\begin{abstract}
The system of strategic priorities and indicators of ecologically sustainable subsoil use is based on a fundamental basis - biotic regulation and it has a systematic character defined by conceptual, ideological, political and economic levels of management. It also possesses strict priorities and is based on interrelated ecological, economic and social factors, it reflects space-time dynamics of development and subsoil use. The indicators of ecologically sustainable subsoil use are indicators that characterize the change of natural, social and economic environment at different times; they provide qualitative and quantitative characteristic of subsoil use problem. The majority of existing sets of indicators of sustainable subsoil use doesn't give a complete picture, is weakly connected with each other and no priorities are distinguished among them.
\end{abstract}

\section{Introduction}

The strategic priorities of ecologically sustainable subsoil use are determined by the necessity of preservation of the environment [1] and creating a favourable socioeconomic sphere $[2,3]$.

Ecologically sustainable subsoil use is a socioeconomic and technological development of subsoil mining complex being carried out in accordance with laws of the biosphere [1] and ecological restrictions. It includes problems of industrial waste landfills technogenic deposits.

\section{Features of subsoil use in the Urals}

Nowadays the main problems in the sphere of subsoil use in the Urals are the following:

For three hundred years more than 8.5 billion tons of wastes from mining, processing, metallurgical, energy and chemical industries have been accumulated having formed 188 technogenic deposits including 95 dumps containing 63 billion tons of overburden and host rocks, non-conditioned ore, sludge and low grade ores. Finely ground wastes being subjected to intensive physical and chemical changes make the strongest negative impact on the environment. For example, almost all sulphites of iron and non-ferrous metals are converted into water-soluble toxic sulphates polluting soil and hydrosphere of the region.

The metallurgical industry of the Urals which is the basis of the whole economic complex of the region requires a lot of import of natural resources from other regions. So, domestic resources of iron ore total 12-14 million of tons while 35 million of tons are necessary to have. About 650-800 thousand tons of chromium are recycled and 600 thousand of them are imported from other regions. Approximately 900 thousand tons of manganese are processed and 600 thousand of them are imported; 50 million tons of coal are consumed in the Sverdlovsk region half of which is imported. There is not much hope on the mega-project "Industrial Urals - Polar Urals" because there are no yet proven reserves of mineral resources [3]. The above mentioned difficulties cause the reduction of the population employment in the sector of subsoil mining and processing of mineral resources;

Table 1. General and primary disease incidence of mental disorders in the areas of subsoil mining in the Middle Urals (calculated per 100000 people)

\begin{tabular}{|l|c|c|c|c|c|c|}
\hline \multirow{2}{*}{ Municipalities } & \multicolumn{3}{|c|}{ Sick rate } & \multicolumn{3}{c|}{$\begin{array}{c}\text { Primary disease } \\
\text { incidence }\end{array}$} \\
\cline { 2 - 8 } & 2008 & 2009 & 2010 & 2008 & 2009 & 2010 \\
\hline Asbest & 1884 & 3254 & - & 335 & 347 & - \\
\hline Kachkanar & 1477 & 1782 & 1898 & 72 & 477 & 393 \\
\hline $\begin{array}{l}\text { Kushva } \\
\text { (Nizhny } \\
\text { Tagil) }\end{array}$ & 2801 & 1777 & 1873 & 331 & 411 & 524 \\
\hline Rezh & 3986 & 3271 & 2601 & 469 & 416 & 461 \\
\hline
\end{tabular}

The lack of complex solution of ecological, economic and social problems in mining of mineral and technogenic deposits and also such negative situations as the decline in volume of mineral deposits development,

\footnotetext{
a Corresponding author: Konstantin.Kokarev@m.ursmu.ru

${ }^{\mathrm{b}}$ The article is prepared with support and as a part of grant RNF №14-18-00564
} 
reduction the number of people working at enterprises and the increase of accumulated environmental damage lead to worsening of health of people (Table 1).

\section{Strategic priorities}

The clearly defined order of strategic priorities of development of subsoil use is:

- environmental;

- social;

- and, finally, economic.

The system of sustainable subsoil use indicators shown in fig. 1.

\subsection{Environmental aspect of subsoil use}

The fundamental role of the environmental aspect is determined by the following:

- without natural (biological) bases there are no grounds for raising the question of the sustainable development of the territory;

- in other fields of knowledge (sociology, economics) there are less methodological clarities on the formation of sustainable subsoil use and the biological aspect gives the opportunity to determine the boundaries of environmental "corridor" of permissible use of natural resources.

- characteristics of the "corridor" are quite objectively and reasonably determined by the flow of energy (or biogenic elements) in natural and anthropogenic channels.

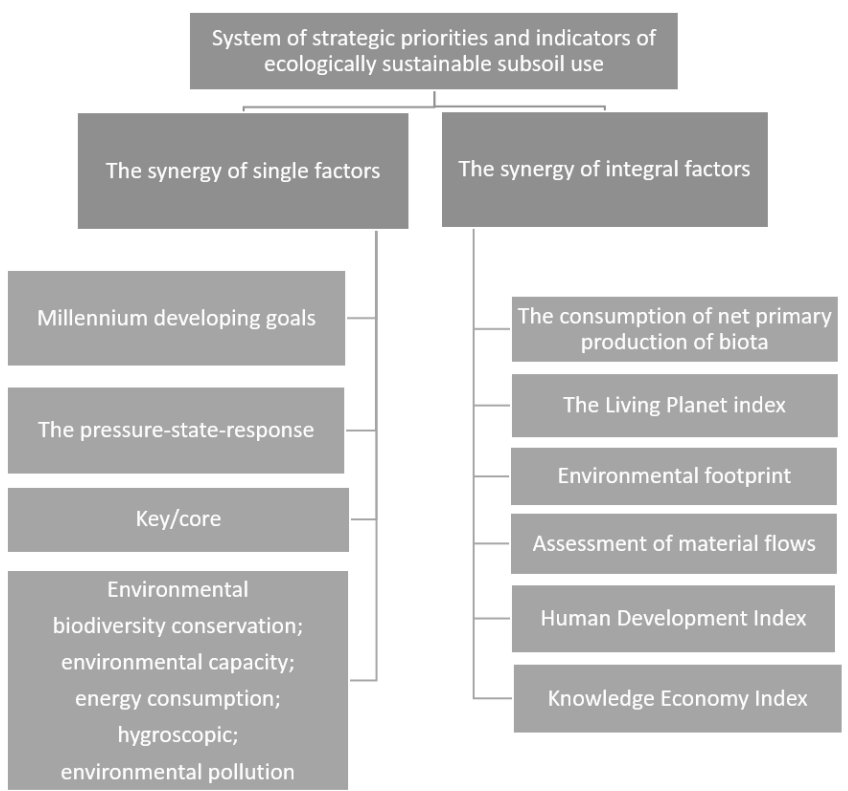

Figure 1. The system of sustainable subsoil use indicators

The scientific fundamental basis of the concept of sustainable subsoil use is the theory of biotic regulation in the environment [4].

\section{The indicators of sustainable subsoil use}

The indicators of sustainable subsoil use are indicators that characterize the change of natural, social and economic environment at different times; they provide qualitative and quantitative characteristic of the problem of subsoil use.

The common systems of indicators [4, 5] are usually formed in order of their popularity and in order of their importance for the certain areas of natural resource use [6]. The popularity is provided by the developers' status (the United Nations Commission for Sustainable Development, the World Bank, the European Union and others). Branches of knowledge and developers define the importance of the existing systems of indicators: economics [7], biology, environmental protection, sociology. It should be noted that the popular and subjective importance of indicators often do not reflect the conceptual values of sustainable development (Rio + 20, Johannesburg - 2002; Rio + 20).

\subsection{Existing system of indicators}

The majority of existing sets of indicators of sustainable subsoil use doesn't give a complete picture, is weakly connected with each other and no priorities are distinguished among them.

For example, the characteristics of subsoil use are usually restricted by geological data [8], technological parameters [9].

\subsection{Environmental indicators of subsoil use}

\subsubsection{Indicators of natural ecosystem status}

The system of strategic indicators of subsoil use reflecting the highest priority in the form of conservation of natural ecosystems includes assessment of the state of natural ecosystems in the regions of subsoil use $[10,11]$ :

- the actual share of natural ecosystems;

- the required share of natural ecosystems;

- the rate of reduction or rehabilitation of ecosystems.

These three indicators describe the state of the territory and the degree of achievement of sustainable subsoil use development. The indicator "the net primary product consumption" from the environment by the society has the same highest priority.

The Table 2 shows the distribution of land area by the degree of its preservation and disturbance in the Middle Urals.

The sustainable development of the biosphere supposes extraction by the man not more than $1-2 \%$ of "net primary product" from it, which corresponds to not more than $10 \%$ of the areas "disturbance" [1]; according to Table 1 there is a sustainable development only in two northern districts of the region. 
Table 2. The distribution of land areas by the degree of its conservation and disturbance in the Sverdlovsk region (2013)

\begin{tabular}{|c|c|c|c|}
\hline $\begin{array}{c}\text { Forest cadaster } \\
\text { area }\end{array}$ & $\begin{array}{c}\text { Undisturbed } \\
\text { lands (land } \\
\text { with } \\
\text { primary } \\
\text { forest } \\
\text { types), \% }\end{array}$ & $\begin{array}{c}\text { Partly } \\
\text { disturbed } \\
\text { lands } \\
\text { agricultura } \\
\text { 1, forest } \\
\text { areas), \% }\end{array}$ & $\begin{array}{c}\text { Disturbed } \\
\text { lands } \\
\text { (settlement, } \\
\text { industrial } \\
\text { objects), \% }\end{array}$ \\
\hline 1.Ivdel-Oussky & 27.6 & 67.7 & 4.7 \\
\hline 2.Serovsky & 24.2 & 67.3 & 8.5 \\
\hline 3.Tavdinsky & 19.3 & 68.8 & 11.9 \\
\hline $\begin{array}{c}\text { 4.Novo- } \\
\text { Lyalinsky }\end{array}$ & 14.8 & 71.5 & 13.7 \\
\hline 5.Nizhny Tagil & 12.7 & 68.9 & 18.4 \\
\hline 6.Alapaevsky & 15.8 & 66.6 & 17.6 \\
\hline 7.Turinsky & 14.4 & 71.2 & 14.5 \\
\hline $\begin{array}{c}\text { 8.Krasnoufimsk- } \\
\text { Shalinski }\end{array}$ & 8.1 & 60.0 & 31.9 \\
\hline 9.Ekaterinburg & 17.2 & 55.2 & 24 \\
\hline 10.Pripyshminsky & 7.4 & 62.8 & 28 \\
\hline The whole area: & 16.8 & 60.9 & 22.3 \\
\hline \multicolumn{2}{|c|}{} & &
\end{tabular}

\subsubsection{Indicators of acceptable subsoil use}

Strategic priorities and indicators can justify the parameters and boundaries of acceptable "corridor" of subsoil use in a particular area; they are based on the system (consisting of a interdisciplinary approach) of the considered questions, on the study of buffer zones of interaction of natural and anthropogenic (including technogenic) factors, on the account of special aspects of the interaction of various factors in restricted areas ("spots") in earlier mined areas, on the account of widely space (industry of the Urals influences on the ecosystems of the Arctic Ocean) and long-term (hydrological regime of regions with flooded mines, cuts) consequences. The specific parameters and boundaries of "corridors" of permissible subsoil use must be defined by the degree of extraction of natural resources, changes in ecological potential, the level of conservation of natural ecosystems, the balance of natural and anthropogenic flows of energy in the environment.

In the Middle and Southern Urals based on existing experience and fragmental research it is offered to carry out searching and mining of mineral deposits by open pits to the depth of 250-300 m establishing enterprises with the life cycle of 10-35 years (The Institute of Mining, Ural Branch of the Russian Academy of Sciences).

In the world and domestic practice, mining in the northern areas is carried out to the depth of 150-200 meters. In severe conditions of the North and Polar Urals this depth cannot be more than $100 \mathrm{~m}$ [8].

\subsubsection{Environmental pollution indicators}

Widely used indicators characterizing environmental pollution have a lower priority as they are of local character; they reflect the state of individual territories. The existing tendency to increase expenses on the environment protection without ecologization of economy (not including environmental impacts on the economy) does not lead to improvement of the air, water, soil and areas in the Urals.

\subsection{Social indicators of subsoil use}

The constitutional parameters characterizing the regulatory and legal framework of subsoil use are social indicators of the sphere of the subsoil use.

At the present stage of social development in Russia it is necessary to ensure preservation and strengthening of the integrated state ownership of the natural resources instead of dividing it into federal, regional and municipal. It is necessary to divide management authorities of the unified state property. The principle of joint decisionmaking on the use and disposal of subsoil (RF Law "On Mineral Wealth") ensures the interests of the state, subsoil users and the regions where the subsoil areas are situated. This principle makes it possible to minimize production risk and smooth out conflicts (economic, ecological, social, national etc.) arising during the prospecting, exploration and mining of mineral resources.

Such indicators allowed solving social, ecological and economic problems of the coal industry in Poland. In the 90th years of the $\mathrm{XX}^{\text {th }}$ century the volumes of coal mining were corrected there, problems of ecological safety of coal mines were solved and the issues of employment were regulated in the given industry. A similar integrated approach was used in Spain (Report of the UN Commission for Rio + 20, 2012, p. 96-98).

The totality of indicators characterizing social aspect also includes such well-known parameters as the "human development index", "adapted net savings", "knowledge economy Index", "composite index of sustainability" and others. Previously unknown factors (the interests of indigenous peoples, accumulated environmental damage) which are not sufficiently considered by the traditional indicators occur in intensively developed northern territories in old industrial regions.

\subsection{Economic indicators of subsoil use}

The totality of economic indicators becomes final in assessment of ecologically sustainable subsoil use. Such indicators as consistent social, economic and ecological evaluation of state of natural resources, assessment of environmentally forming potential of areas of subsoil use, evaluation of social significance, consistent social, economic and ecological evaluation of limits and limits of natural resource use, assessment of comparing natural and industrial potentials are of the highest priority among the economic indicators.

In most economic studies on assessment of the natural resources and phenomena the relationship between certain natural components (between resource potential, environmentally forming and social functions) are not sufficiently taken into account, regional and territorial peculiarities of ecological functions are ignored, the ecosystemic character of assessed objects and phenomena is not considered. The main idea of existing economic assessment work on biological objects and phenomena is their identification with physical objects (real estate). 
Table 3 and 4 show the results of calculation of the annual effect of the ecological potential in the structure of gross regional product and the results of assessment of the environmental territory wealth (in the form of cadastral value) in the structure of the whole regional wealth.

\subsubsection{Indicators of economic capacity}

Table 3. Evaluation of the effect of ecological potential in the structure of gross regional product area (Sverdlovsk region, 2012)

\begin{tabular}{|l|c|}
\hline \multicolumn{1}{|c|}{ Indicators } & 2012 \\
\hline $\begin{array}{l}\text { The annual effect of the ecological potential of the territory, } \\
\text { million dollars: }\end{array}$ & $\$ 137.5$ \\
\hline the value of absorbed $\mathrm{CO}_{2}$ & $\$ 178.5$ \\
\hline the value of produced $\mathrm{O}_{2}$ & $\$ 630.4$ \\
\hline The gross regional area product, million dollars: \\
\hline agriculture & $\$ 516$ \\
\hline development of mineral deposits & $\$ 1057$ \\
\hline electricity production & \\
\hline
\end{tabular}

Table 3 shows the importance of the annual effect of the ecological potential of the territory. Its value is comparable to the gross regional product in the Sverdlovsk region in certain sectors of the economy.

\subsubsection{Indicators of economic wealth}

Table 4 clearly shows the importance of the natural potential in the regional territory wealth - it is comparable to the cost of the capital fund in certain sectors of the economy.

Table 4. Evaluation of the ecological wealth of the territory in the structure of the whole regional wealth (Sverdlovsk region,

$$
\text { 2012) }
$$

\begin{tabular}{|l|c|}
\hline \multicolumn{1}{|c|}{ Indicators } & 2012 \\
\hline $\begin{array}{l}\text { The cost of the ecological potential of the territory, million } \\
\text { dollars: }\end{array}$ \\
\hline - the cadastral value of the absorbed $\mathrm{CO}_{2}$ & $\$ 6583$ \\
\hline - the cadastral value of produced $\mathrm{O}_{2}$ & $\$ 5642$ \\
\hline \multicolumn{2}{|l|}{ The cost of capital funds in the region, million dollars: } \\
\hline - agriculture & $\$ 1128.5$ \\
\hline - development of mineral deposits & $\$ 928.6$ \\
\hline - manufacturing & $\$ 10857$ \\
\hline - electricity production & $\$ 4264$ \\
\hline
\end{tabular}

\subsubsection{Indicators of mining complex}

The indicators of complex use of natural deposits and retreatment of technogenic deposits are primarily aimed at identifying contradiction between the conceptual purpose and regional conditions of production, at the characteristics of these contradictions and justification of actions taken to achieve sustainable development of the territory. Table 5 shows the parameters that characterize the importance of the mining complex in the industrial potential of the Sverdlovsk region.

In the Middle Urals despite the relatively small share of mining industry in the gross regional product (less than $6 \%$ ) and even smaller share of workers in this sector in the regional economy (less than 3\%), the sector of subsoil use provides metallurgical and processing enterprises, the share of which in the region totals $60 \%$.

Table 5. The indicators characterizing the importance of the mining complex in Sverdlovsk region

\begin{tabular}{|l|c|c|c|}
\hline \multicolumn{1}{|c|}{ Indicators } & 2006 & 2008 & 2010 \\
\hline $\begin{array}{l}\text { The gross regional product, } \\
\text { million dollars }\end{array}$ & $\$ 11660$ & $\$ 16482$ & $\$ 18678$ \\
\hline $\begin{array}{l}\text { The gross regional product } \\
\text { in the field of subsoil use, } \\
\text { million dollars }\end{array}$ & $\$ 664.2$ & $\$ 960.7$ & $\$ 1033.9$ \\
\hline $\begin{array}{l}\text { The gross regional product } \\
\text { in processing, million } \\
\text { dollars }\end{array}$ & $\$ 6767.8$ & $\$ 8812.5$ & $\$ 8476.8$ \\
\hline $\begin{array}{l}\text { The number of workers in } \\
\text { the economy of the region, } \\
\text { th. people. }\end{array}$ & 1609.5 & 1642.6 & 1579.4 \\
\hline $\begin{array}{l}\text { The number of workers in } \\
\text { the sector of subsoil use, } \\
\text { th. people. }\end{array}$ & 46.6 & 39.5 & 31.9 \\
\hline $\begin{array}{l}\text { The number of workers in } \\
\text { the sector of processing } \\
\text { production, th. people. }\end{array}$ & 461.0 & 436.0 & 362.6 \\
\hline
\end{tabular}

The traditional economic indicators of "rational use of natural resources" have a lower priority.

All considered indicators of sustainable development of subsoil use correspond to the international understanding of environmental safety and are supported by international standards [9].

\section{Conclusion}

Thus, the proposed system of strategic priorities and indicators of economically sustainable subsoil use:

- is based on the fundamental scientific basis - biotic regulation, being the basis of life on the Earth;

- has a systematic character defined by the conceptual, ideological, political and economic levels of the management of sustainable development of regions of subsoil use and the need for system approach in solving the problems of sustainable development proposed at the Forum "Rio + 20";

- possesses strict priorities; for example, the realization of regional programs on "environmental protection" and the rational use of natural resources is performed only with preliminary coordination with the "corridors" of permissible economic activity - limits of extraction of resources from the environment;

- is based on interrelated environmental, economic and social factors allowing in certain integral indicators "human development index", "adapted net savings", " economy knowledge index", "composite index of stability" and others to consider the fundamental principle of life - biotic regulation in the environment; 
- reflects space-time dynamics of development of natural ecosystems, economic externalities, relationships (contradictions, conflicts) between interests of individual natural resource users and public preferences.

\section{References}

1. V.G. Gorshkov, Physical and biological fundamentals of life stability. M., VINITI, 1995, XXX VIII, $472 \mathrm{p}$.

2. Hotelling H. Economics of Exhaustible Resources // Jorn. Polit. Econ. 1931. Vol. 39. Apr., P. 137-175

3. Shell K., Stiglitz J.E. The Allocation of Investment in a Dynamic Economy // Quart. Journ. Econ. 1967, Vol. 81. Nov.

4. S.N. Bobylev, "Green" economy in Russia: new approaches and indicators. Mat. of the 12th Intern. Conf. RSEE. Irkutsk, 2013, pp. 13-16.

5. G.E. Mekush, Environmental policy and sustainable development: analysis and methodological approaches // Ed. S.N. Bobylev; The Ministry of Education and Science of the Russian Federation; Kemerov State. Univ / - Moscow: Economics, 2011. $-255 \mathrm{p}$.

6. V.B. Zharnikov, A.I. Gagarin, T.A. Lebedeva, About priorities of indicators of sustainable development of the territory // Bulletin of the SSGA (Siberian State
Academy of Geodesy) / Vol. 4 (28), Novosibirsk, SSGA, 2014, pp. 57-65.

7. S.N. Bobylev, N.V. Zubarevich, S.V. Solovyov, Y.S. Vlasov, Sustainable development: methodology and measurement techniques. Work book. - M., Economics, 2011. - 358 p.

8. V.A. Koroteev, K.S. Ivanov, N.V. Vakhrusheva, Mega-project "Industrial Urals - Polar Urals". Contemporary state. Collection "Ways of realization of oil-gas and ore potential of Khanty-Yugra". Khanty-Mansiysk. Publishing house "IzdatNaukaServis", 2011, pp. 96-104.

9. V.L. Yakovlev, S.V. Kornilkov, Methodological features of development of mineral resources at the present stage. Bulletin Ural Branch of the Russian Academy of Sciences, 2013, No. 4. pp. 11-18.

10. Y.V. Lebedev, V.A. Azarenok, T.A. Lebedeva, Indicators of sustainable development and ecologization of the economy in the Ural region. Coll. mat. RSEE. Kemerovo. 2011, pp. 49-52.

11. Y.V. Lebedev Assessment of the forest ecosystem, in environmental economics. - Yekaterinburg: UB RAS, 2011. -574 p.

12. Solow Robert M. Economic theory of resources or resources of economic theory. (Lecture in honor of Rigarod T. Elite. St. Petersburg: The School of Economics (ed. V. Galperin). 